\title{
Læring i videnssamfundet - Om vidensformidling, videnskonstruktion og vidensdeling
}

\section{Jørgen Bang}

Lektor

Institut for Informations- og Medievidenskab, Aarhus Universitet.

\section{Christian Dalsgaard}

Post doc.

Institut for Informations- og Medievidenskab, Aarhus Universitet.
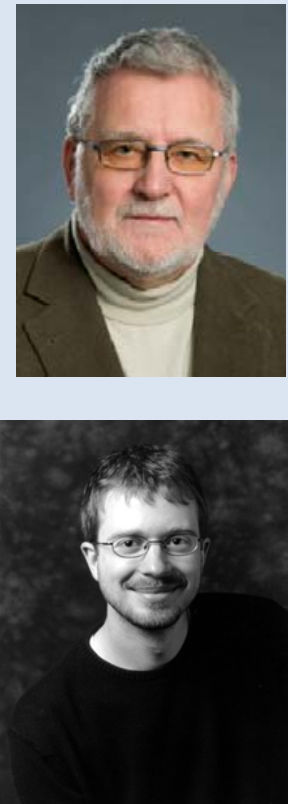

\section{Indledning}

Denne antologi fremlægger resultaterne fra forskningsprojektet Videnskonstruktion, vidensdeling og vidensformidling i videnssamfundets uddannelsessystem under Det Humanistiske Fakultets satsningsområde Videnssamfundet. Artiklerne er skrevet af forskere ved Aarhus Universitet samt af forskere udefra, som har deltaget i projektet med oplæg dels på seminarer og workshops afholdt af Center for IT ved Institut for informations- og medievidenskab, Aarhus Universitet, dels på den 
afsluttende konference om "Knowledge Media", Aarhus Universitet (Januar 19-20, 2009).

Artiklerne undersøger, hvordan medier kan understøtte vidensdeling, fostre videnskonstruktion og bidrage til vidensformidling inden for uddannelse, i kulturbærende institutioner samt i uformelle sammenhænge. Artiklerne diskuterer perspektiverne i at anvende Web 2.0, mobiltelefoner, podcasting, virtuelle verdener, digitale arkiver, mm. i forbindelse med læring.

I indledningen gøres der rede for den forståelse af begrebet 'viden' som er gennemgående for artiklerne, og det diskuteres om begrebet 'vidensmedier' kan anvendes som en samlende optik for udforskningen af relationerne mellem viden og medier i videnssamfundet. Derefter følger en kort oversigt over karakteristika ved de nye medier som introduceres i artiklerne. Til slut gives et samlet overblik over tematikkerne i antologiens artikler.

Tidsskriftet udgives både i html- og pdf-format. I pdf-formatet er indlejret medieklip, og man kan således downloade al indhold i artiklerne. I htmludgaven er det tilstræbt at gøre det muligt at læse artiklerne på mobile enheder. Her er der ikke indsat medieindhold for at understøtte hurtig indlæsning.

\section{Hvad er viden?}

En sociokulturel forståelse af viden opgiver forestillingen om, at viden alene befinder sig i individets hoved, og at viden kan eksternaliseres i bøger og lignende. Det er ikke muligt at isolere viden fra menneskets aktive liv, sociale og praktiske kontekst og den kultur, mennesket lever i. Denne forståelse af viden får betydning for den rolle, medier kan spille for menneskets videnstilegnelse og for, hvordan man kan tænke formidling gennem medier. I overskrifter siger den sociokulturelle vidensforståelse:

- Viden eksisterer i udførelse af handlinger

- Viden er anvendelse af redskaber i handlinger

- Viden er situeret i sociale praksisser

Ifølge den sociokulturelle tilgang optages viden ikke fra omgivelserne som stimuli gennem sanserne. Videnstilegnelse kræver aktiv deltagelse fra individet. Ikke blot i form af aktiv tænkning, men i form af handlinger, der har et formål, et mål eller et sigte. Med andre ord eksisterer viden i udførelse af handlinger. Som Dewey (1916: 275) bekendtgjorde allerede i 1916: "[...] there is no such thing as genuine knowledge and fruitful understanding except as the offspring of doing." Med andre ord er viden bundet til udførelse af handlinger og opstår i brug. Som Säljö (2003) skriver, skal begrebet redskab forstås bredt: 
"Ved redskab eller værktøj forstås de ressourcer, sproglige (eller intellektuelle) såvel som fysiske, som vi har adgang til, og som vi anvender, når vi forstår vores omverden og handler i den." (Säljö, 2003, p. 21)

I forlængelse af handlingers betydning for viden knytter den sociokulturelle tilgang først og fremmest viden til praksis (Chaiklin \& Lave 1996) - såvel i betydningen af en konkret, fysisk praksis som den processuelle udførelse af praksissen. Lave \& Wenger (Lave \& Wenger 1991; Wenger 1998) beskriver, hvordan viden og læring knytter sig til deltagelse i praksisfællesskaber, og hvordan viden ikke kan flyttes fra praksisfællesskabets kontekst. Suchman (1987) understreger videns kontekstafhængighed, idet hun skriver, at handlinger er situerede, hvilket indebærer, at viden knytter sig til selve den umiddelbare situation for menneskets handlinger. Viden er med andre ord relativ til individets kontekst. Menneskets handlinger i en praksis foregår ikke isoleret fra andre mennesker, men placerer sig altid inden for en sociokulturel praksis. Ud over forståelse af egne "lokale" mål og hensigter må mennesket derfor samtidig forstå egne handlinger i relation til en overordnet sociokulturel praksis. Menneskets individuelle handlinger finder deres betydning i en større kollektiv sammenhæng, der indeholder andre mennesker og andre handlinger og mål (Leontjev 1983). Dermed bliver andre menneskers handlinger centrale for at forstå egne handlinger. Konsekvensen for viden er, at viden er relativ til den sociale kontekst, mennesket handler inden for (Dalsgaard 2007). Social interaktion i form af kommunikation og deltagelse bliver i den forbindelse vigtig for at sikre relationer mellem mennesker med henblik på at opnå indsigt i hinandens handlinger og praksis. At viden er knyttet til redskaber og til en social praksis indebærer, at man kan tale om, at viden er distribueret i praksis. Viden er både distribueret fysisk og socialt. Fysisk i form af fysiske objekter, der kan anvendes som redskaber til at udføre handlinger (Hutchins 1995). Socialt er viden distribueret mellem mennesker i sociale strukturer (Hutchins 1996; Säljö 2003; Salomon 1993).

\section{Viden og medier}

Ved forskningsprojektets afsluttende konference i januar 2009 lancerede vi begrebet 'knowledge media' eller 'vidensmedier' som samlende overskrift. Inspirationen fik vi fra Open University's Knowledge Media Institute der blev etableret i 1995. I en publikation fra 1998 (Eisenstadt \& Vincent, 1998) definerer de 'knowledge media' på følgende vis:

"Knowledge Media is about the process of generating, understanding and sharing knowledge using several different media, as well as understanding how the use of different media shape these processes".

Det centrale i denne definition er den dobbelte eller dialektiske bevægelse - det processuelle, hvor medierne på en gang bidrager til at skabe, forstå og 
dele viden, samtidig med at medierne er forudsætningen for processen gennem medialiseringen og derved også sætter grænser for hvad det er muligt at udtrykke/formidle/forstå:

Medier er ikke i sig selv vidensmedier - det er anvendelsen af medierne, der gør dem til vidensmedier.

Vidensmedier forudsætter, at medierne anvendes til videnskonstruktion, vidensformidling og vidensdeling i forskellige sammenhænge - f.eks. inden for uddannelse, i organisationer, inden for kulturbærende institutioner samt i uformelle formidlingssammenhænge.

Vidensmedier fokuserer på de processer som generer viden og forståelse gennem medieret kommunikation - ikke mindst de nye muligheder som internettet i samspil med digitale og mobile teknologier giver for just-intime og just-in-place adgang til informationer.

Når man betragter medier gennem optikken vidensmedier og ud fra en sociokulturel forståelse, er medier potentielle vidensmedier i den forstand, at de potentielt kan understøtte individets videnskonstruktion.

Konsekvensen er, at fokus flyttes fra mediet selv til de handlinger, individet anvender mediet til at udføre. Det er anvendelsen af mediet, der er det centrale. Vidensmedier kan defineres som medier, der anvendes af individet til at konstruere viden. Det er en meget bred definition, men pointen er ordet "anvendelse". Det er først, når de anvendes til videnskonstruktion, at de bliver til vidensmedier. Medier kan forstås som redskaber til videnskonstruktion, der finder sted gennem anvendelsen af medier.

Formidling af viden sker ikke som en transmission af indhold fra en afsender til en modtager. Viden skabes i modtageren som et resultat af at han eller hun gør en indsats for at integrere indholdet med den viden som vedkommende allerede har. Rob Koper fra det hollandske åbne universitet udtrykker det på denne måde: “(...) a lot of learning does not come from knowledge resources at all, but stems from the activities of learners solving problems, interacting with real devices, interacting in their social and work situation (...) it is the activities of the learners into the learning environment, which are accountable for the learning." (Koper, 2001 p.3). For at vidensformidling skal fungere optimalt er det med andre ord nødvendigt at brugerne finder det formidlede indhold relevant - har brug for det. I forhold til organiserede læreprocesser initieres denne proces ved at underviseren igangsætter forskellige læringsaktiviteter (Bang 2006). Ved uformelle læreprocesser - f. eks. ved besøg på museer, udstillinger, m.m. - og ved andre former for formidling af viden er det et spørgsmål om at den indre motivation - interessen - vækkes hos modtageren, så han eller hun selv iværksætter bearbejdningsprocessen. 
Jørgen Bang har tidligere (Bang 2000 \& 2004) lanceret følgende kommunikationsmodel for medieret kommunikation inspireret af Stuart Halls artikel (1980) om 'encoding' og 'decoding'. Artiklen er skrevet i opposition til effektforskningens fiksering på en lineær stimulus-respons model for mediereception, men udbygges her til en generel model for medieret kommunikation.

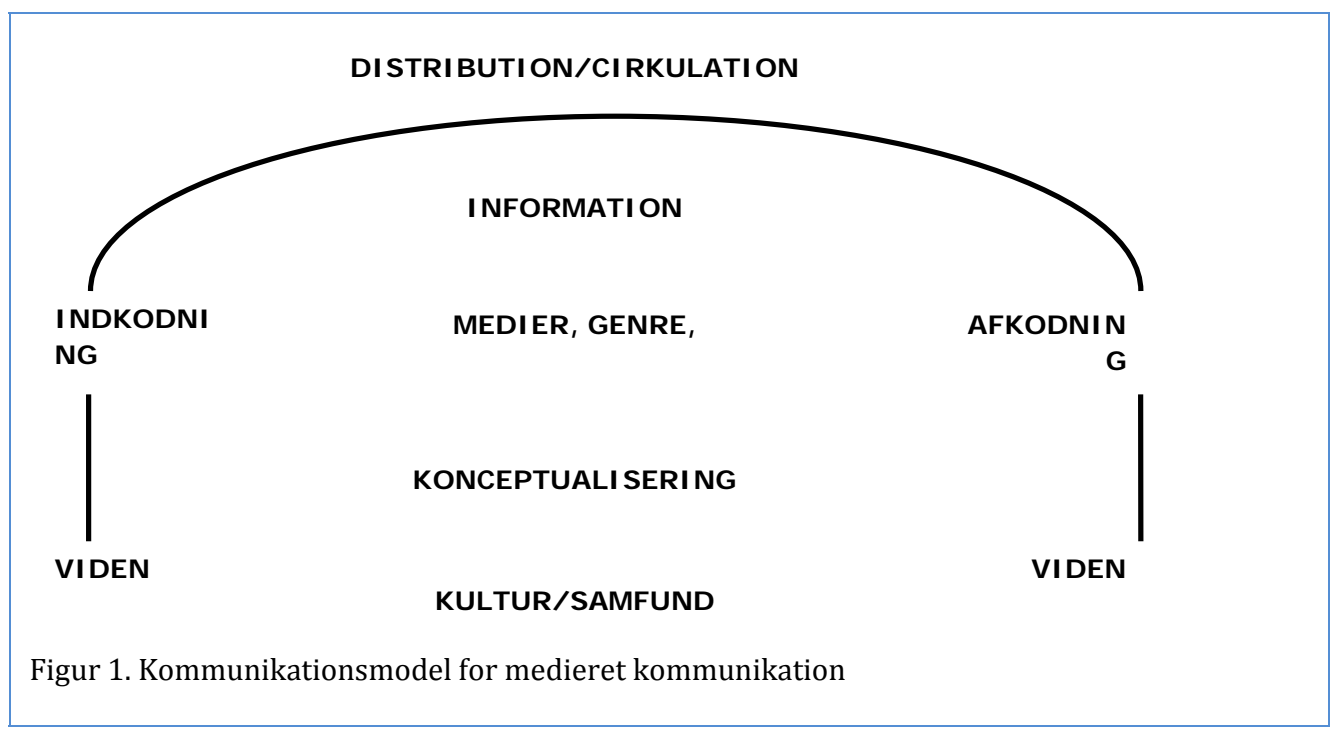

For at viden kan formidles må den konceptualiseres og indkodes i et sprog som tekst $i$ en genre og i et medie. Først når den foreligger som medieformidlet 'budskab', som information, kan den distribueres til andre. Det gælder både for verbalt formidlede budskaber og for budskaber i andre medier: trykte tekster, analoge tekster (audio, video), digitale tekster m.m. Forudsætningen for, at denne indkodning kan lykkes, er en fortrolighed med de koder, der gælder i det samfund, hvor kommunikationen finder sted. Sagt med Folke Larsens terminologi skal operationel viden udtrykkes sprogligt/symbolsk som deklarativ viden (Folke Larsen 1984). Først når viden fremtræder i deklarativ form kan den cirkuleres til andre via medier.

For at modtagelsen eller receptionen skal give mening skal der sker en afkodning af budskabet. Indkodning og afkodning er således parallelle processer, men uden at være synkroniseret så der er garanti for at resultatet bliver det samme - at modtageren faktisk forstår afsenderens budskab på den måde, som det er tænkt. Når det lykkes at kommunikere skyldes det at afsender og modtager deler sprog og kultur, er fortrolige med de samme tekstuelle, genre- og mediemæssige konventioner samt konceptualiserer på tilnærmelsesvis samme måde.

Denne medieforståelse indebærer, at medier ikke kan organisere og formidle et indhold af viden fra et individ til et andet, men kan muliggøre, at der sker en aktivering af individet så han/hun begynder at reflektere og 
reorganisere de nye informationer i relation til tidligere erfaringer. Bente Elkjær (2000) sammenfatter - i forlængelse af Dewey - processen meget præcist:

"The separation between cognition and practice is replaced by a continuity of knowing and acting. Dewey regarded education as growth, or rather a growing process, i.e. a continuous process that is part of the development of life. Although learning takes place in social situations, it is the individual learner who learns, and learns through reorganizing and reconstructing her/his experience. (...)

Thus, experience is not mere activity, mere doing, and it is not only change, but change that implies reflection on former actions in order to anticipate further consequences. The mere participation in practice, in action, does not create learning. Only a person who is able to reflect upon her/his own actions and reorganize as well as reconstruct experience by continuously employing reflection - thinking - as means of action is learning". (Elkjaer 2000: 353)

Med begrebet vidensmedier rettes fokus på den del af kommunikationsprocessen, hvor indholdet tilegnes/afkodes af brugeren. Spørgsmålet om, hvordan medier kan understøtte brugerens aktive refleksion og bearbejdning af indholdet sættes i centrum. Vidensmedier er altså ikke medier i betydningen "medieret formidling", men er derimod medier som redskaber for individets tilegnelse af viden; medier for udførelse af handlinger, herunder refleksion. Ifølge det sociokulturelle vidensbegreb skal medier ikke blot organisere og formidle et indhold til individet, men skal også muliggøre, at individet kan udføre forskellige aktiviteter i tilknytning til receptionen (Dalsgaard 2007). Udfordringen for vidensmedier ligger i, hvordan medier kan medvirke til at igangsætte læringsaktiviteter.

Alle medier kan i princippet betragtes som vidensmedier, men ikke alle medier er lige velegnede som vidensmedier. Eksempelvis har tv og radio overvejende formidlende karakteristika i deres envejskommunikerende form, men det betyder ikke, at individet ikke kan anvende tv og radio til at konstruere viden. Andre medier har imidlertid et større potentiale til at understøtte individets selvstændige videnskonstruktion. Digitale medier computere og internettet - muliggør således interaktivitet, der aktiverer brugeren, samtidig med at de understøtter en række samarbejds- og kommunikationsformer.

Artiklerne i denne antologi diskuterer potentialerne i nye digitale medier i relation til vidensdeling, videnskonstruktion og vidensformidling. Men før vi præsenterer antologiens indhold vil vi forsøge at sætte dens mediemæssige ramme med en kort beskrivelse af en række af de centrale teknologier, der markerer den ny udvikling på internettet. 


\section{Digitale medier: Medierne i videnssamfundet}

Anvendelsen af digitale medier har medført, at mediernes rolle har ændret sig, og ifølge Finnemann $(2001 ; 2005)$ er en ny type medie ved at forme sig. Internettet giver adgang til enorme mængder af digitale materialer og giver samtidig mulighed for brugernes aktive deltagelse. Sidstnævnte indebærer social interaktion i form af kommunikation og samarbejde. Derudover indebærer det brugergenereret indhold eksempelvis i form af weblogs og wikier. Anvendelsen af digitale medier er udtryk for nye former for vidensdeling og vidensformidling, og dermed aktualiseres begrebet vidensmedier.

Som nævnt udfordrer internettet og digitaliseringen forståelsen af vidensdeling og vidensformidling. Det umiddelbare potentiale i digitale medier har medført en række satsninger inden for området på nationalt (Videnskabsministeriet 2003), EU- (Commission of the European Communities 2005) og internationalt plan (UNESCO 2005; The New Media Consortium 2007). Satsningerne relaterer sig især til udvikling af videnssamfund og har primært fundet sted inden for uddannelse. Eksempler på sådanne satsninger er e-læringssystemer og digitale biblioteker. Der er siden slutningen af 1990'erne investeret store summer i e-læringsprojekter, og adskillige virtuelle universiteter er oprettet til fjernundervisning. I dag er status, at stort set alle de virtuelle universiteter har været fiaskoer, og mange er lukkede (Bang 2006). Samtidig er adskillige digitale biblioteker 1 blevet udviklet med henblik på deling af digitale materialer. På trods af flere års arbejde med at udvikle metadatastandarder og kategorisere materialer har de digitale biblioteker imidlertid ikke fundet en stor brugergruppe.

Med dette in mente er det interessant at rette blikket mod de nye digitale medier, der ofte går under betegnelserne Web 2.0, social software eller sociale medier (Freedman 2006; Dalsgaard 2006; iCrossing, 2007). De forskellige begreber vidner om en forvirring om, hvordan man skal forstå og definere den seneste udvikling på internettet.

\section{Weblog}

En weblog er en hjemmeside, der består af en række daterede indlæg placeret i omvendt kronologisk rækkefølge. Ofte er en weblog personlig og varetages af et enkelt individ. Weblogs adskiller sig fra traditionelle hjemmesider ved primært at bestå af løbende indlæg i modsætning til et statisk indhold. Samtidig er det let for læsere af en weblog at følge med i opdateringer, da en weblogs RSS feeds (se nedenfor) muliggør, at man kan abonnere på nye indlæg. Weblogs er derfor velegnede til løbende indlæg og ikke til organisering og formidling af information. I sig selv er en weblog

\footnotetext{
${ }^{1}$ Eksempelvis http://www.merlot.org og http://careo.ucalgary.ca/.
} 
individuel og lægger ikke meget op til dialog. Dog er det muligt for læserne af en weblog at skrive kommentarer til webloggens indlæg. Disse kommentarer er også synlige for andre læsere, og på den måde kan der opstå dialog på webloggen. Kommunikation i weblogs finder imidlertid også sted på en anden måde. Ofte knytter brugere af weblogs sig sammen i netværk, hvor de læser hinandens indlæg. I stedet for blot at knytte en kommentar kan man lave en trackback, der henviser til et indlæg på sin egen weblog, der omhandler og responderer på det samme emne. Det indebærer, at emnet for et indlæg kan blive spredt og diskuteret på tværs af netværket. Resultatet er en forgrenet kommunikationsstruktur, hvor emner kan spredes i forskellige sammenhænge. Eksempler på software til at oprette weblogs er Blogger og Wordpress.

\section{Wiki}

Wiki-teknologien kendes bedst fra online opslagsværket Wikipedia, der er en brugergenereret encyklopædi. En wiki er en hjemmeside, der kan redigeres direkte på nettet af alle, der har adgang til den. Ved hjælp af hyperlinks er det muligt at konstruere en ikke-lineær tekst i en wiki. Wikiens egentlige styrke ligger i dens understøttelse af samarbejde. En wiki lægger op til en løbende udvikling af en hjemmeside eller en tekst, og brugerne har altid adgang til den nyeste udgave af wikien. En wiki behøver ikke nødvendigvis at være åben for hele verden. Det er muligt at lukke for en wiki, således at eksempelvis kun en mindre gruppe har adgang til at redigere i wikien. Ud over Wikipedia kan nævnes wikiHow og Wikitravel som eksempler på wikier.

\section{Sociale fællesskaber}

Internettet er rum for mange former for sociale fællesskaber. For det første i form af diskussionsfora, hvor brugere kan diskutere fælles interesser. Diskussionsfora giver brugerne mulighed for at stille spørgsmål til andre og dermed indgå i direkte dialog. Derudover opstår sociale fællesskaber i social networking sites såsom Facebook og MySpace. Social networking sites er karakteriseret ved, at brugeren har en profil i form af en personlig side. Profilen udgør brugerens repræsentation i fællesskabet. Brugeren kan løbende ændre sin profil ved at tilføje og redigere indholdet. Profilen danner udgangspunkt for social interaktion, idet den muliggør, at andre kan se profilen. En bruger kan skabe relationer til "venner", der også har oprettet en profil. Dermed opbygger brugeren sit eget personlige netværk. Et netværk adskiller sig fra et diskussionsforum, idet netværket er unikt og personligt for den enkelte bruger, mens diskussionsfora udgør et fælles rum for alle deltagere. Som konsekvens adskiller kommunikationen sig også. I netværket kan brugerne følge med i hinandens aktiviteter og læse om hinanden uden nødvendigvis at kommunikere direkte. Kommunikation i sociale netværk kan have form af indirekte kommunikation, hvor 
brugerne følger med i hinandens opdateringer af profiler. Den indirekte kommunikationsform handler først og fremmest om synlighed mellem deltagerne eller vennerne i netværket (Dalsgaard 2008; Paulsen 2008; Dalsgaard \& Paulsen 2009). Sociale netværk gør det let at følge med i opdateringer, nye indlæg, etc. og gør dermed brugere synlige for hinanden. Endelig kan der som nævnt opstå sociale fællesskaber i netværk af weblogs. Social interaktion i netværk af weblogs kan have form af kommentarer eller respons på egen weblog. Derudover er netværk af weblogs ligeledes velegnede til den indirekte kommunikationsform, der også karakteriserer social networking sites. Brugere kan læse og følge med i mange weblogs uden nødvendigvis at kommentere eller respondere.

\section{Media sharing services}

Ud over betegnelsen media sharing services kaldes tjenester til deling af forskellige medier som videoer og billeder også content communities. Eksempler er YouTube, flickr og Slideshare. På tjenesterne kan brugere uploade billeder, videoer, etc. og dele dem med andre. Tjenesterne organiserer materialerne anderledes end biblioteker. Media sharing services er ikke blot lagre af digitale materialer; de er samtidig sociale netværk. Før man kan uploade materialer, skal man oprette en profil, som ens materialer tilknyttes. Med andre ord er materialerne altid koblet på en person eller en profil. Ud over at uploade egne materialer kan man også knytte sine foretrukne materialer til sin profil. Det indebærer, at brugere får adgang til hinandens foretrukne videoer, billeder, etc. Når brugere ligesom i sociale netværk - knytter sig til venner, kan de eksempelvis holde sig opdateret med, hvilke videoer vennerne ser og producerer. Konsekvensen er, at samme digitale materiale bliver repræsenteret $\mathrm{i}$ mange forskellige sammenhænge, i forskellige sociale netværk. Brugeren bliver gjort opmærksom på nye materialer gennem sit netværk. Kommunikation og udveksling i media sharing services er dermed ligesom sociale netværk et spørgsmål om synlighed. Yderligere finder kommunikation sted gennem de kommentarer, brugerne kan skrive til materialerne. Dermed opstår en diskussion om materialerne. Eksempelvis diskuterer brugere af flickr kvaliteten af billeder og giver hinanden råd om fotografering.

\section{Social bookmarking og tagging}

Lige som man kan gemme sine foretrukne hjemmesider (bookmarks) $\mathrm{i}$ browseren på sin pc, kan man gemme dem på tjenester på nettet. For det første muliggør det, at brugeren altid har adgang til sine bookmarks, så længe han/hun har adgang til nettet. Social bookmarking-tjenester som del.icio.us og Furl gør det derudover muligt at se hinandens bookmarks. Tjenesterne har paralleller til media sharing services, idet brugere kan dele hjemmesider med hinanden. Ved hjælp af RSS feeds kan brugere følge med 
i, hvilke hjemmesider deres "venner" bookmarker. Dermed understøtter social bookmarking indirekte kommunikation og synlighed mellem brugere. Relateret til social bookmarking er begrebet tagging. Når en bruger bookmarker en side, giver han/hun den en række tags til at karakterisere hjemmesiden. Et "tag" er et mærke i form af et nøgleord. En sideeffekt af tagging i social bookmarking-tjenester er en kategorisering af internettets hjemmesider. Det er brugerne, der i fællesskab bestemmer, hvordan en hjemmeside skal kategoriseres. På tjenesterne kan man se, hvordan brugere har kategoriseret hjemmesider. Denne anvendelse af tagging betegnes "folksonomy", der skal ses i modsætning til taksonomier.

\section{Podcasting}

Podcasting er på mange måder en traditionel publikationsform i form af envejskommunikation. Podcasting består af distribution af video- eller lydklip. Det nye - i forhold til streaming - er, at filerne kan downloades og overføres til mobile enheder (pods). Samtidig og måske mere vigtigt understøtter podcasting RSS, hvilket indebærer, at man kan abonnere på podcasts. Podcasting er dermed en fleksibel distributionskanal, hvor brugere kan udvælge bestemte serier af podcasts, som automatisk bliver opdateret.

\section{RSS feeds}

RSS er ikke en tjeneste, men en teknologi, der ligger til grund for meget af den sociale infrastruktur på nettet. RSS muliggør, at man kan abonnere på forskellige tjenester ved hjælp af en feed reader. Feed readeren holder øje med nye feeds fra tjenester som eksempelvis weblogs. Teknologien muliggør, at brugeren ikke behøver at besøge tjenester for at se, om der er nyt, men i stedet bliver opdateret i feed readeren. En bruger kan nemt følge med i mange forskellige tjenester og konstant være opdateret.

\section{Virtuelle verdener}

Virtuelle verdener er simulationer, hvor brugeren kan bevæge sig rundt $\mathrm{i}$ en 3-dimensionel verden. Eksempler på virtuelle verdener er Active Worlds og Second Life. Typisk navigerer brugeren rundt i den virtuelle verden gennem en avatar, der er brugerens repræsentation i den virtuelle verden. Eftersom mange virtuelle verdener eksisterer online, kan utallige personer mødes i virtuelle verdener på tværs af geografiske afstande. Samtidig giver de virtuelle verdener brugeren mulighed for selv at konstruere bygninger og lignende til den virtuelle verden.

\section{Mobile enheder}

Til sidst skal mobile enheder nævnes. Mobiltelefoner besidder i dag en multifunktionalitet, der betyder, at mobilerne kan anvendes til et utal af formål som at spille musik, tage billeder, optage video, lagre billeder, etc. 
Endelig kommer mobiltelefonerne i stigende grad på nettet, hvilket indebærer, at man via sin mobiltelefon i princippet har adgang til ovennævnte tjenester på sin mobiltelefon.

\section{Antologiens artikler}

Ovenstående er eksempler på de nye medier i videnssamfundet. I denne antologi diskuterer artiklerne, hvordan disse medier kan udnyttes til vidensformidling, videnskonstruktion og vidensdeling. Antologien er inddelt i tre temaer: 1) Sociale medier, 2), Mobile medier og 3) Medier i undervisningen.

Første del om Sociale medier diskuterer perspektiverne i anvendelsen af internettet til videnskonstruktion og vidensdeling. Artiklerne fokuserer på internettets udvikling i retning af en mere social og brugerdeltagende anvendelse, der ofte betegnes Web 2.0.

I antologiens første artikel E-læring 2.0. Vilkår og muligheder i det sociale $\underline{w e b}$ afdækker Simon Heilesen begrebet e-læring 2.0. De grundlæggende kendetegn ved e-læring 2.0 er ifølge Heilesen mulighederne for at udvikle personlige læringscentre, deltage i sociale netværk og anvende sociale medier som læringsværktøj. E-læring 2.0 sætter den lærende i centrum og muliggør, at individet kan trække på forskellige ressourcer og dermed konstruere sit personlige læringscenter. Samtidig deltager individet gennem sit personlige læringscenter i sociale netværk på nettet, der muliggør, at institutionelle grænser nedbrydes. Endelig indebærer e-læring 2.0 anvendelsen af internettet som læringsværktøj i form af et udvalg af værktøjer til individuel tilrettelæggelse og kollaborativt samarbejde, hvilket skal ses i modsætning til centraliserede e-læringssystemer. Heilesen argumenterer for, at Web 2.0-teknologier kan være medvirkende til at realisere en vision, der har eksisteret i flere år inden for netbaseret læring i form af brugerstyret læring i sociale netværk.

Marianne Riis sætter i artiklen Mon Wenger har en avatar? - observationer og refleksioner over remediering af didaktisk design i Second Life fokus på virtuelle verdeners læringspotentiale. Artiklen beskriver et pilotforsøg med anvendelse af Second Life på en masteruddannelse, hvor studerende har udforsket Second Life. Pilotforsøget fremhæver sprogindlæring, rollespil og andre gruppeaktiviteter, simulationer og 3D-konstruktion og visualisering som centrale læringspotentialer i anvendelsen af virtuelle verdener. Pilotforsøget demonstrerer, at Second Life er vanskeligt at blive fortrolig med, og at der skal bruges tid på at lære den virtuelle verden, før man kan inddrage den i en læringssammenhæng. Når deltagerne imidlertid har opnået en fortrolighed med den virtuelle verden, argumenterer Riis for, at det er muligt at skabe nærværende fællesskaber i en virtuel verden. Dette har blandt andet perspektiver i forhold til fjernundervisning, hvor deltagere kan mødes, kommunikere og samarbejde i virtuelle verdener. 
I artiklen Internettet som personligt og socialt medie diskuterer Christian Dalsgaard potentialerne i internettet til at formidle og konstruere viden. Dalsgaard argumenterer for, at nye former for vidensdeling og vidensformidling kan opstå ved at anvende internettet som personaliseret og socialt medie. Med udgangspunkt i begreberne om personaliserede og sociale vidensmedier fremlægger artiklen en række karakteristiske egenskaber ved internettet som vidensmedie. Internettet i egenskab af vidensmedie udmærker sig ved at muliggøre narrowcasting og selektion, synkron og asynkron kommunikation, synlighed og indirekte kommunikation og kobling af mennesker og information. Artiklens diskussion af internettet som personaliseret og socialt vidensmedie peger på, at uddannelsesinstitutioner og kulturinstitutioner har mulighed for at anvende internettet til at tilbyde information i form af materialer såvel som personer i situationer og sammenhænge, der bevæger sig ud over institutionernes tilrettelagte uddannelsesforløb, udstillinger og hjemmesider.

Jørgen Bang griber i artiklen Den digitaliserede kulturarv - en leringsressource med stort potentiale! fat i projekter, der har til formål at gøre kulturarv i en digital form tilgængelig for forskning, uddannelse og videnstilegnelse i al almindelighed. Artiklen betragter digitaliseret kulturarv som en læringsressource, og med udgangspunkt i EU-projektet Europeana og det danske projekt Danske Reklamefilm om digitalisering af reklamefilm diskuterer artiklen læringspotentialerne i digitaliseret kulturarv. Bang argumenterer for, at der er et potentiale i materialesamlinger som Danske Reklamefilm, idet de besidder en pædagogisk åbenhed, der indebærer, at de kan anvendes i forskellige læringsscenarier og af forskellige brugere eller studerende. Samlingerne har dermed et særligt potentiale i forbindelse med problem- og projektorienteret arbejde.

Antologiens anden del om Mobile medier behandler potentialerne og perspektiver i anvendelse af mobile medier i læringssammenhænge og til vidensformidling. Især sætter artiklerne fokus på, hvordan mobile medier kan være medvirkende til at nedbryde grænser mellem formelle og uformelle situationer for læring og videnskonstruktion.

I den første artikel om mobile medier Mobile mediers læringspotentialer didaktiske overvejelser i forbindelse med brugen af podcast og vodcast giver Bo Fibiger et overblik over begreberne mobil læring og pod/vodcast. Fibiger kaster et kritisk blik på begrebet mobil læring og diskuterer styrker og svagheder ved anvendelsen af mobile medier i en læringssammenhæng. Artiklen tager udgangspunkt i en diskussion af læringspotentialerne i podcast, hvor Fibiger fremhæver distributionen af podcasts i form af feedbaseret abonnement som en styrke. Samtidig understreger artiklen, at podcasts har begrænsninger pga. manglen på interaktion og 
kommunikation. Derfor argumenterer Fibiger for, at podcasting skal tænkes ind i en bredere pædagogisk sammenhæng, der inkluderer kommunikation og samarbejde. I kraft af sin multifunktionalitet rummer mobilen netop en række nye muligheder for at understøtte problemorienteret kollaborativ læring, og artiklen argumenterer for, at mobilens særlige styrker er dens kombinerede mulighed for dataindsamling, produktion og kommunikation.

Artiklen Mobiltelefoner som kulturelle ressourcer: En analyse af mobil ekspertise, strukturer og spirende kulturelle praksisser af Ben Bachmair, John Cook og Norbert Pachler omhandler mobil læring i grænselandet mellem formelle og uformelle kontekster. Artiklen tager sit afsæt i en konstatering af, at elever uden for klasselokalet deltager i og udvikler en kultur, der indeholder en række frugtbare mediekompetencer med relevans for skolen. I artiklen argumenterer Bachmair, Cook og Pachler for, at man bør inkorporere denne spirende kulturelle praksis i skolebaseret læring. Med udgangspunkt i to cases viser artiklen, hvordan mobiltelefoner kan være medvirkende til at inkludere elevers mediekompetencer i skolen. Desuden argumenterer artiklen for, at skoler bliver nødt til at restrukturere for at leve op til de nye kulturelle praksisser, der findes uden for skolen, samt at en anerkendelse af, hvordan mobile enheder kan anvendes, kan bidrage til at inkorporere elevernes kultur og kompetencer uden for skolen.

I artiklen Kan brugen af mobiletelefoner i undervisningen styrke elevcentrerede læreprocesser? fortsætter Judith Seipold i sporet om mobil læring. Det centrale spørgsmål i artiklen er, hvordan der skabes relationer mellem elevers kulturelle praksisser og uformelle læring uden for skolen og læring inden for skolens rammer. Med baggrund i en række eksempler viser artiklen, hvordan mobiltelefonen er tænkt ind i en skolesammenhæng i forskellige projekter inden for m-læring. Mobiltelefonen betragtes som et centralt middel til at skabe læring på tværs af formelle og uformelle kontekster, men samtidig identificerer Seipold et modsætningsforhold mellem anvendelsen af mobiltelefoner uden for skolen og i skolen. Mens mobiltelefonen oftest anvendes som kommunikationsmiddel i hverdagen uden for skolen, bliver den ofte et dokumentationsredskab i skolen.

Klaus Rummler fortsætter i artiklen "Udsatte elevers" livsstil: Indbyrdes afhængigheder mellem mønstre for mediebrug og læring $i$ "udsatte" ungdomskulturer temaet om mobil læring. Rummler argumenterer indledningsvist for, at det er vigtigt at have indblik i de livsverdener og mønstre for mediebrug, som eleverne bringer med sig fra deres liv uden for skolen. Artiklen beskriver forskellige segmenter og fremlægger forskelle i mediebrug inden for segmenterne. Dernæst rettes fokus specifikt mod "udsatte elevers" livsstil og deres mønstre for mediebrug uden for skolen i relation til forskellige medier. Undersøgelsen af "udsatte elever" viser, at deres nuværende mediebrug står i kontrast til den formelle læring i skolen. 
For de "udsatte elever" er mobilen et personligt og transportabelt mobilt arkiv til personlige medieproduktioner eller til opbevaring af personlige medieressourcer. I en skolesammenhæng ligger der derfor et potentiale i at engagere "udsatte elever" i samarbejdsmæssige, selvstændige læringssituationer og at give dem digitale hukommelseskort, som kan forbedre deres meningsdannelse med medier.

I artiklen Kan mobiltelefonen skabe refleksion i undervisningen? Medialisering som refleksivt redskab sætter Jørgen Bang og Christian Dalsgaard fokus på mobilens potentiale for at styrke elevernes refleksion over eget arbejde. Artiklen tager afsæt i et casestudie fra Moesgård Museum i Århus, hvor folkeskoleelever anvendte mobiler i forbindelse med udstillingen RØR VERDEN. På udstillingen kunne eleverne røre ved genstande fra museets UNESCO-samling, og samtidig skulle de anvende mobiltelefoner til at dokumentere deres erfaringer med henblik på at præsentere dem for de øvrige elever. På baggrund af casen argumenterer artiklen for, at der er et læringspotentiale i anvendelsen af mobilen som personligt værktøj. For det første kan mobiltelefonen anvendes til at dokumentere og formidle erfaringer i form af historier, og for det andet kan mobiltelefonen bidrage til at skabe et refleksivt rum, hvor eleverne bearbejder deres erfaringer.

I antologiens tredje del om Medier i undervisningen diskuterer artiklerne, hvordan medier kan integreres og arbejdes med i undervisningen.

I artiklen Brug af podcasts $i$ undervisningen - muligheder og begrænsninger analyserer Helle Mathiasen resultaterne af en empirisk undersøgelse af brugen af podcasts på et universitetskursus. Artiklen anlægger en systemteoretisk optik på underviserens og de studerendes erfaringer med forskellige typer podcasts. I undersøgelsen har de studerende arbejdet med podcasts i form af korte præsentationer og demonstrationer samt længere forelæsninger. De studerende i undersøgelsen ser potentialer i podcasts, men er også kritiske over for teknologien. Blandt andet viser undersøgelsen, at de studerende har svært ved at koncentrere sig om længere forelæsninger, og at det samtidig kræver for meget koncentration at se podcasts på farten via mobile enheder. Endelig betragter de studerende ikke en videooptaget forelæsning som en erstatning for tilstedeværelsesundervisning, men nærmere som supplerende inspiration. På den anden side påpeger de studerende, at især korte podcasts kan være nyttige ressourcer, men det helt afgørende er, at underviser ikke fokuserer på mediet i sig selv, men på hvordan mediet er tænkt ind i undervisningen.

I antologiens afsluttende artikel Det eksperimenterende fællesskab: Børn og voksnes leg med medier og teknologi præsenterer Ole Caprani og Klaus Thestrup en pædagogik, der nedbryder en traditionel forståelse af medier og teknologi i uddannelsessammenhæng. Gennem artiklen udvikler Caprani og Thestrup pædagogikken det eksperimenterende fællesskab, hvor børn og voksne i fællesskab leger og eksperimenterer med medier og 
teknologi. Artiklen præsenterer erfaringer fra en langt række eksperimenter, der har været medvirkende til udviklingen af pædagogikken. I eksperimenterne arbejder børn og voksne med medier og teknologi på en udforskende og eksperimenterende måde, hvilket indebærer, at børnene skiller teknologi og legetøj ad og samler det igen på nye måder. Artiklen fremlægger konkrete pædagogiske principper for, hvordan børn og voksnes fælles møde med medier og teknologi kan tage form.

\section{Litteratur}

Bang, J. (2000). Distribueret Uddannnelse, Om dialog, refleksion og fleksibilitet i IKT-støttet læring, IN: Heilesen, Simon (red.). At Undervise med IKT, Samfundslitteratur, p. 195-216

Bang, J. (2004). Hvorfor er vidensdeling så svært? - om vidensorganisering og læring som kommunikation IN: Heilesen, Simon, ed.: Det digitale nærvær. Viden og design i nye medier, Roskilde Universitetsforlag, p. 13-31

Bang, Jørgen (2006). eLearning reconsidered. Have e-learning and virtual universities met the expectations? elearningeuropa.info. http://www.elearningeuropa.info/index.php?page=doc\&doc_id=7778\& doclng=6\&menuzone $=1$.

Bang, J., Dalsgaard, C. 2008, Digital forskningsformidling - Kommunikative potentialer ved at anvende Web 2.0 til videnskonstruktion, IN: Læring og Medier, nr. 1, http://www.forskningsnettet.dk/da/Lom10

Chaiklin, Seth \& Lave, Jean (red.) (1996). Understanding practice. Perspectives on activity and context. Cambridge University Press.

Commission of the European Communities (2005). i2010 - A European Information Society for growth and employment. http://ec.europa.eu/information_society/eeurope/i2010/docs/commu nications/com_229_i2010_310505_fv_en.pdf.

Dalsgaard, Christian (2006). Social software: E-learning beyond learning management systems, European Journal of Open, Distance and ELearning, 2006/II. http://www.eurodl.org/materials/contrib/2006/Christian_Dalsgaard.h tm (15.8.2006).

Dalsgaard, Christian (2007). Åbne læringsressourcer - mod en sociokulturel teori om læringsressourcer. Ph.d.-afhandling, Medievidenskab, Aarhus Universitet. 
Dalsgaard, Christian (2008). Social networking sites: Transparency in online education. EUNIS 2008 proceedings, Århus, June 24 - 27, 2008. http://eunis.dk/papers/p41.pdf.

Dalsgaard, Christian \& Paulsen, Morten Flate (2009). Transparency in Cooperative Online Education, The International Review of Research in Open and Distance Learning (IRRODL), Vol. 10, No. 3. http://www.irrodl.org/index.php/irrodl/article/view/671.

Eisenstadt, M. \& Vincent, T., eds. (1998):The Knowledge Web, Kogan Page, 1998 , p. 4

Folke Larsen, S. (1984). Kognitionens logikker. Handling, sprog og datamater, I: Psyke \& Logos årg. 5. Nr. 2, Dansk Psykologisk Forlag, København, p. 221-242

Finnemann, Niels Ole (2001). The Internet - A New Communicational Infrastructure. Skrifter fra Center for Internetforskning. 02

Finnemann, Niels Ole (2005). Internettet i mediehistorisk perspektiv. København: Samfundslitteratur.

Freedman, Terry (red.) (2006). Coming of Age - An introduction to the NEW worldwide web. http://fordlog.com/?page_id=100.

Hutchins, Edwin (1995). "How a Cockpit Remembers Its Speeds." Cognitive Science 19: 265-288.

Hutchins, Edwin (1996). Learning to Navigate. I: Chaiklin, Seth \& Lave, Jean (red.). Understanding practice, kap. 2, s. 35-63. Cambridge University Press.

iCrossing (2007). What is social media? www.icrossing.co.uk/ebooks.

Koper, R. (2001). Modeling units of study from a pedagogical perspective. The pedagogical meta-model behind EML, http://dspace.ou.nl/handle/1820/36

Lave, Jean \& Wenger, Etienne (1991). Situated learning: Legitimate peripheral participation. Cambridge University Press.

Leontjev, A. (1983). Virksomhed. Bevidsthed. Personlighed. Sputnik.

Paulsen, Morten Flate (2008). Cooperative Online Education. Seminar.net, 4(1). http://www.seminar.net/current-issue/cooperative-onlineeducation.

Säljö, Roger (2003). Læring i praksis: et sociokulturelt perspektiv. København: Hans Reitzels Forlag.

Salomon, Gavriel (1993). Distributed cognitions. Cambridge University Press.

Suchman, Lucy A. (1987). Plans and situated actions. Cambridge University Press. 
The New Media Consortium (2007). The Horizon Report: 2007 Edition. http://www.nmc.org/horizon/.

UNESCO (2005). Towards Knowledge Societies. UNESCO Publishing. http://unesdoc.unesco.org/images/0014/001418/141843e.pdf.

Videnskabsministeriet (2003). It med omtanke - It og telepolitisk handlingsplan.

http://videnskabsministeriet.dk/site/forside/publikationer/2003/itmed-omtanke---it--og-telepolitisk-handlingsplan-2003 (25.2.2007).

Wenger, Etienne (1998). Communities of Practice. Cambridge University Press. 